\title{
Sleep Abnormalities in Pregnancy: Review
}

\author{
Gebelikte Uyku Bozuklukları
}

\author{
Ayla AÇAR ESER, ${ }^{a}$ \\ İkbal KAYGUSUZ, \\ illknur INEGÖL GÜMÜŞ, ${ }^{2}$ \\ Aydın KÖŞÜŞ, ${ }^{a}$ \\ Nermin KÖşÜŞa
}

${ }^{a}$ Department of Gynecology and Obstetrics, Turgut Özal University Faculty of Medicine, Ankara

Geliş Tarihi/Received: 22.04.2014

Kabul Tarihi/Accepted: 13.10 .2014

Yazışma Adresi/Correspondence: Ayla AÇAR ESER

Turgut Özal University Faculty of Medicine, Department of Gynecology and Obstetrics, Ankara,

TÜRKIYE/TURKEY

aylaacar76@yahoo.com.tr

doi: 10.5336/gynobstet.2014-40269

Copyright $(92015$ by Türkiye Klinikleri

\begin{abstract}
Pregnancy and sleep disorders are strongly correlated. Sleep disorders commonly experienced in pregnancy include insomnia, restless legs syndrome, excessive daytime sleepiness and sleep disordered breathing, for example sleep apnea. Causes can be physical discomfort, hormonal changes, alterations in respiratory physiology and psychological and emotional upheaval. Incidence of the different types of sleep disorders varies depending on pregnancy trimester. The first trimester is associated with excessive daytime sleepiness, although this can continue throughout pregnancy. Physical factors such as nausea and vomiting and hormonal changes are important causes. By the second trimester, hormonal changes are stabilising but women may still suffer sleep problems due to enlarged abdomen causing low back pain, abrupt fetal movements, heartburn and nocturia. In the third trimester, the majority of women suffer from sleep problems. Incidence of insomnia and restless legs syndrome reach their maximum. Sleep disordered breathing issues including sleep apnea, snoring and hypoventilation are also more common, influenced by rising progesterone levels, disordered and periodic breathing, excessive weight gain and altered neck circumference. Sleep disorders in pregnancy have been associated with adverse maternal and fetal outcomes. Treatment options include improving sleep hygiene, exercise, positional therapy, continuous positive airway pressure, behavioural therapies and, where the sleep disorders are refractory to these types of interventions, short-term pharmacological treatment with suitable hypnotics. Postpartum, many of the pregnancy-associated sleep disorders resolve, however many women continue to experience excessive daytime sleepiness and both pre- and post-partum sleep disorders have been linked to incidence of post-natal depression.
\end{abstract}

Key Words: Sleep; pregnancy; sleep disorders

ÖZET Gebelik ve uyku bozuklukları arasında kuvvetli bir ilişki vardır. Gebelikte sıklıkla yaşanan uyku bozuklukları insomnia, huzursuz bacak sendromu, gündüz aşırı uyku hali ve uyku apnesi gibi uykuda nefes bozukluklarıdır. Nedenleri fiziksel rahatsızlık, hormonal değişiklikler, solunum fizyolojisindeki değişimler, psikolojik ve duygusal sarsıntılardır. Çeşitli tipteki uyku bozukluklarının insidansı trimesterlere göre değişiklik göstermektedir. İlk trimester gündüz aşırı uyku hali ile ilişkilidir, ancak bu durum gebelik boyunca devam edebilir. Bulantı kusma gibi fiziksel faktörler ve hormonal değişiklikler önemli nedenlerdir. İkinci trimesterle birlikte hormonal değişiklikler stabilize olur fakat kadınlar, genişlemiş karnın neden olduğu sırt ağrısına, ani fetüs hareketlerine, mide yanması ve noktüriye bağlı olarak, uyku problemlerinden hala şikayetçi olabilirler. Üçüncü trimesterde kadınların büyük çoğunluğu uyku problemleri yaşayabilirler. İnsomnia ve huzursuz bacak sendromu insidansı maksimum seviyeye ulaşır. Yükselen progesteron düzeyleri, düzensiz ve periyodik solunum, aşırı kilo alımı ve değişmiş boyun çevresinden etkilenen, uyku apnesi, horlama ve hipoventilasyon dahil olmak üzere uyku solunum bozukluğu sorunları da daha sık görülür. Gebelikte uyku bozuklukları olumsuz maternal ve fetal sonuçlar ile ilişkilendirilmiştir. Tedavi seçenekleri uyku hijyeni, egzersiz, pozisyonel terapi, sürekli pozitif hava yolu basıncı, davranışsal terapiler ve bu tür önerilere cevap vermeyen uyku bozukluklarında uygun hipnotiklerle kısa süreli farmakolojik tedavi uygulamasını içerir. Doğum sonrası, hamilelik kaynaklı bir çok uyku bozukluğu ortadan kalkar, fakat bir çok kadın gündüz aşırı uyku hali sorunu yaşamaya devam eder, doğum öncesi ve sonrası uyku bozuklukları doğum sonrası depresyonla ilişkilendirilmiştir.

Anahtar Kelimeler: Uyku; gebelik; uyku bozuklukları

Turkiye Klinikleri J Gynecol Obst 2015;25(4):250-7 


\section{OVERVIEW}

1 leep abnormality and pregnancy are strongly correlated, with between 75 to $80 \%$ of pregnant women around the world experiencing some form of sleep disturbance during this period. ${ }^{1}$ Both hormonal changes and physical discomforts associated with pregnancy have been associated with sleep problems in pregnant women., ${ }^{2,3}$ Pregnancy may also exacerbate existing sleep disorders. ${ }^{4}$ Common sleep abnormalities associated with pregnancy include insomnia, restless legs syndrome and excessive sleepiness. ${ }^{4}$ Furthermore, alterations in respiratory physiology during pregnancy result in sleep-disordered breathing (SDB) and hence disorders such as obstructive sleep apnea are also common. ${ }^{5}$ The three trimesters of pregnancy are each associated with different challenges to sleep quality. Each trimester brings different physiological and psychological issues, altering the type and degree of sleep abnormality. Usually, sleep becomes more fragmented, and the quality of sleep declines furthest in the third trimester. ${ }^{6}$ Likelihood of developing sleep disorders during pregnancy will also be influenced by factors including pre-existing sleep disorders, mental disorders such as anxiety or depression or certain personality traits. ${ }^{7,8}$

\section{INCIDENCE OF COMMON SLEEP DISORDERS IN PREGNANCY}

Incidence of the common sleep disorders varies depending on the trimester of pregnancy, although exact prevalence of sleep disorders in pregnancy is difficult to define absolutely. ${ }^{8}$ Excessive sleepiness, in particular increased daytime sleepiness, is a feature of the first trimester of pregnancy, but continues to be observed throughout the pregnancy. ${ }^{3,9}$ Incidence of rhinitis in pregnancy has been reported to be between $18-42 \%$ and is accompanied by nasal congestion and inflammation, causing sleep disturbance. While nasal congestion is observed during the first trimester, its incidence is higher later in pregnancy. ${ }^{10}$

During the second trimester, the probability of sleep abnormality increases from first trimester's average of $13 \%$ to $19 \% .{ }^{11}$ While women may not experience the same level of excessive sleepiness, slow-wave sleep (SWS) level begins to drop, and regular REM sleep rate may increase or decrease. The number of mid-night awakenings also begins to increase from two to four times per night, accounting for a disturbed sleep cycle during this period of pregnancy. Moorcroft asserts that "by the middle of pregnancy sleep has returned to typicalfor-age levels but falls below these levels later in the pregnancy". ${ }^{11}$

Insomnia is observed throughout pregnancy but is particularly prevalent in the third trimester. For example, one recent study of 2,816 women in week 32 of pregnancy in Norway estimated insomnia prevalence of $61.9 \% .{ }^{12}$ Prevalence of depressive symptoms in this cohort stood at $14.6 \%$ and was strongly correlated with insomnia. Meanwhile, a Turkish study of 486 pregnant women estimated a prevalence of $52.2 \%$ insomnia, with incidence doubling in the third trimester compared to the first and second. ${ }^{13}$ Incidence of restless legs syndrome is also mainly associated with the third trimester and has been estimated at between 19$26 \%$ of pregnant women in studies in various different countries. ${ }^{14-17}$

Sleep apnea, including obstructive sleep apnea (OSA), is a problem that may affect many pregnant women, especially in the second and third trimesters. ${ }^{18}$ While prevalence of obstructive sleep apnea is difficult to be exact about, the reported increased incidence of snoring during pregnancy, ranging from $15 \%$ to $27 \%$ of pregnant women among studies, suggests that OSA prevalence is higher than in the general population. ${ }^{3,19}$ Swedish studies on groups of 500 or more pregnant women showed that during the last week of pregnancy 21.2-23\% of women reported nightly snoring every night compared to only $4 \%$ before pregnancy. ${ }^{20,21}$ In another study, 267 participants underwent ambulatory monitoring and polysomnography during their last antenatal six visits and their blood pressure upheavals, sleep abnormalities and other symptoms were recorded. The analysis revealed that abnormal respiratory patterns persisted during the third trimester, with $11.8 \%$ of participants reporting snoring in this period..$^{22}$ 


\section{ETIOLOGY OF SLEEP DISORDERS IN} PREGNANCY

\section{FIRST TRIMESTER}

\section{Physical and Emotional Issues}

In the first trimester, the most common sleep issues include waking due to the frequent urge to urinate especially at night, which directly and negatively impacts the sleep cycle of a pregnant woman. The sleep cycle is also often disturbed due to nausea and vomiting and the emotional stress associated with pregnancy. ${ }^{4,8,19}$

The urge to urinate occurs due to the increasing pressure on the bladder caused by the rapid development of the fetus within the uterus. The body's demand for proper sleep results in excessive daytime sleepiness. Results of one study indicated that there is a mean increase in daytime sleep hours from week 1 of pregnancy, reaching more than 30 minutes by 11 weeks. ${ }^{6}$ Although the sleep time increases, the quality of subjective sleep decreases resulting in decreased sleep efficiency and sleep REM. "Insomnia and excessive sleepiness" have both been categorized as "Pregnancy-associated Disorders" by the International Classification of Sleep Disorders. ${ }^{3}$

\section{Hormonal Changes}

The hormonal changes that women undergo during pregnancy, especially in the first trimester, can result in emotional stress which disturbs their sleep cycle, leading to insomnia. ${ }^{23}$ During the first trimester, there are major changes in levels of the reproductive hormones, with levels of estrogens and progesterone increasing throughout pregnancy. ${ }^{3}$ Increment in estrogen levels can negatively modify the respiratory system by stimulating mucosal edema, capillary congestion, hyperemia and fragility of the upper tract. ${ }^{10}$ Other hormones such as placental growth hormone and non-hormonal causes such as smoking, allergies and infections have also been implicated in rhinitis and nasal congestion in pregnancy. ${ }^{10}$

\section{SECOND TRIMESTER}

During the second trimester, hormonal balance is achieved as progesterone levels elevate more grad- ually, nausea tends to come under control, and pressure on the bladder reduces because the fetus moves above it. ${ }^{23}$ However, during this period pregnant women may still suffer sleep problems, including poor sleep quality, difficulty in getting to sleep, frequent arousal and excessive daytime sleepiness. ${ }^{24}$ Etiological factors during the second trimester include enlarged abdomen causing low back pain, abrupt fetal movements leading to arousals during sleep, heartburn and nocturia. Backache is observed in the majority of pregnant women in all three trimesters. In a study comprising 950 pregnant women conducted by Yale University School of Medicine's Department of Anesthesiology, it was noted that 645 respondents declared backache as the main cause of sleep disturbance throughout the pregnancy. ${ }^{25}$ This is not only because of the burden of the baby on the belly but also due to the softening of ligaments between pelvic bones and slackening of joints, as a woman's body becomes prepared for childbirth.

\section{THIRD TRIMESTER}

\section{Physical Issues}

During the third trimester, common sleep disturbance etiologies include frequent urination, backache, discomfort caused by rapid and strong fetal movement, general discomfort due to enlarged belly, fatigue, shortness of breath and heartburn. In fact, the majority of women experience sleep disturbances during the third trimester. ${ }^{3,26,27}$ In one questionnaire-based study on 325 women, it was reported that only $1.9 \%$ of women did not report nocturnal wakening at this point in pregnancy. ${ }^{6}$ However, despite decreases in nocturnal sleep time in comparison to the first two trimesters, the mean 24-hour sleep time of pregnant women comes close to the sleep average of the pre-pregnancy period. Day-time naps become regular during this phase, adding additional hours to the 24-hour average sleep time.

\section{Sleep-disordered Breathing Conditions}

Sleep-disordered breathing (SDB) conditions, including sleep apnea, snoring and hypoventilation are all more common in the third trimester due to changes in the respiratory system and sleep physi- 
ology during pregnancy. ${ }^{28}$ Sleep apnea is a common issue in the second and particularly in the third trimester. Increased progesterone levels contribute to this condition, which causes alterations in respiratory function leading to abnormal breathing patterns. Heightened hypercapnia ventilator response and alterations in chest wall proprioceptors, facilitated by the respiratory stimulation of progesterone, lead to sleep apnea and dyspnea. The most common type of dyspnea is the "physiologic dyspnea" in which the pregnant woman becomes short of breath either while at rest or during mild activity. ${ }^{17}$ Sleep Apnea worsens during the third trimester as the pregnant woman gains weight and the baby grows completely.

Obstructive and central sleep apnea are other common types of sleep apnea in pregnant women. The primary stimulators of these problems are disordered and periodic breathing, excessive weight gain and altered neck circumference along with nocturnal obesity hypoventilation syndrome. Snoring and increased nocturnal blood pressure are common in obstructive sleep apnea. One recent study showed that obstructive sleep apnea is strongly associated with both hypertension and snoring in pregnant women. ${ }^{29}$ Women start to snore more regularly in the third trimester; this heightened tendency to snore is reported by at least $14 \%$ of pregnant women in the final phase of pregnancy.3 Snoring, and obstructive sleep apnea are associated with rhinitis. Central apnea is also associated with disturbed respiratory functioning. Obesity is a predictive factor in obstructive sleep apnea and snoring in pregnancy. ${ }^{30}$

\section{Restless Legs Syndrome}

Restless Legs Syndrome (RLS) is also more common by the third trimester of pregnancy. ${ }^{16}$ This is a neurosensory disorder, and typically the main effects of the syndrome are experienced during the evenings, making it difficult to fall asleep. ${ }^{14}$ Outside of pregnancy, it has been linked to anemia due to iron deficiency and to dopaminergic pathways. It has been suggested that the major contributory mechanisms to RLS pathophysiology in pregnancy are hormonal changes and iron and folate status. ${ }^{14,31}$ For example, one study showed that pregnant women with RLS had both low serum ferritin at preconception and significantly reduced levels of folate at preconception and at each trimester. ${ }^{14}$ Another study on 642 pregnant women showed that women with RLS had lower hemoglobin levels and mean corpuscular volume. ${ }^{16}$

\section{Mental Health}

Studies indicate that insomnia in pregnancy is more common among women with depressive symptoms. ${ }^{12,13}$ Personality traits have also been identified as potentially important causative factors in insomnia in pregnancy, for example, one study has suggested that the personality traits Neuroticism and Agreeableness are associated with insomnia in pregnancy. ${ }^{7}$

\section{PREVENTION AND TREATMENT OF SLEEP DISORDERS IN PREGNANCY}

\section{CONSEQUENCES OF SLEEP DISORDERS IN PREGNANCY}

Sleep disorders in pregnancy can have serious consequences for both mother and baby, so prevention and treatment are crucial. For example, SDB in pregnancy has been variously associated with hypertension, pre-eclampsia and gestational diabetes, although there is some lack of consensus in the literature. ${ }^{3,29,32}$ One recent study on 1,673 women in the third trimester of pregnancy linked maternal snoring during pregnancy to adverse delivery outcomes including cesarean delivery and smallfor-gestational age. ${ }^{33}$ The presence of OSA in a cohort of 175 obese pregnant women was associated with more frequent pre-eclampsia, neonatal intensive care unit admissions, and cesarean deliveries. ${ }^{34}$ Another study on 128 second-trimester and 120 third-trimester pregnant women and their newborns suggested that poor sleep quality was significantly associated with greater risk of vacuum-assisted delivery. ${ }^{35}$ An emerging theory suggests that SDB, with its accompanying sleep fragmentation and intermittent hypoxemia, may contribute to miscarriage risk, making SDB treatment a possible intervention for subsequent pregnancies. ${ }^{36}$ In terms of mental health, while women 
with pre-existing depressive symptoms may be more at risk of sleep disorders during pregnancy, on the other hand, sleep disorders can lead to impaired psychosocial functioning at all stages of pregnancy, including increased depressive symptoms. ${ }^{3,12,37,38}$

\section{TREATMENT AND PREVENTION}

Thus, it is of great importance for both mother and foetus that sleep disorders in pregnancy be identified and treated. Both pharmacological and nonpharmacological interventions are available for prevention and treatment of insomnia but in pregnancy it would be desirable to attempt nonpharmacological interventions where possible. Identification of women at higher risk in the earlier stages of pregnancy would be of benefit in attempting to avoid recourse to drugs that might have adverse effects on the fetus or mother. Initiating prenatal care early on for females having a history of chronic mood disorders, hypertension, irregular blood pressure upheavals, depression and/or anxiety can be helpful in preventing sleep disorders and ensuring successful outcomes in pregnancy.

In general in treatment of insomnia, Ramakrishnan recommends first addressing issues of sleep hygiene and exercise. ${ }^{39}$ This would include steps such as undergoing relaxation therapies and changing bedding, using extra-soft pillows, having a hot water bath before going to bed and to listening to soothing music. Reducing the amounts of caffeine and nicotine also helps in promoting better sleep patterns. ${ }^{39}$ These kind of steps, aimed at addressing pregnancy-associated complaints such as the typical physical discomforts, would be particularly relevant in pregnancy once specific sleep disorders have been excluded by taking a medical history. ${ }^{3}$ Interventions including cognitive behavioral therapy have been shown to be effective in assisting with elements of insomnia, including adjusting attitudes and beliefs and teaching techniques to overcome the sleeplessness. ${ }^{39}$ This type of psychotherapeutic approach is particularly relevant considering the preponderance of depressive and anxiety symptoms among pregnant women with sleep disorders. ${ }^{12,13}$ It is also important to test at-risk women in the earlier stages of pregnancy so that drugs that might have adverse effects on the fetus or mother might be able to be avoided by early behavioral interventions. Initiating prenatal care early on for women with a history of chronic mood disorders, hypertension, irregular blood pressure upheavals, depression and/or anxiety can be helpful in ensuring successful outcomes of pregnancy.

However, if sleep hygiene interventions or behavioral therapies prove ineffective and daytime functioning is being impaired, it may be necessary to turn to short-term pharmacological treatment. However, many sedative-hypnotics such as benzodiazepines have are considered to confer risk in pregnancy, being associated, for example, with 'floppy infant syndrome' and respiratory depression. ${ }^{3}$ Therefore, it is essential to identify suitable hypnotic agents in which risk of fetal harm is considered unlikely. For example the imidazopyridine drug Zolpidem has been considered relatively safe for use in pregnancy, although some studies suggest that its use, particularly in high dose, may be associated with adverse outcomes including low birth-weight infants, preterm deliveries, small for gestational age infants, and cesarean delivery or even fetal neural tube defects. ${ }^{40,41}$

RLS, which is associated with low serum ferritin and folate levels, can lead to sleep deprivation and severe mood swings. ${ }^{14}$ This disease could be prevented by increased awareness of the importance of testing the serum levels of ferritin and folate during the earliest period of pregnancy and making sufficient efforts to keep these levels within normal range.

For SDB in pregnancy, in some cases positional therapy may be sufficient, for example in cases of positional OSA. ${ }^{3,5}$ However, often continuous positive airway pressure (CPAP) is the most appropriate treatment for countering SDB during pregnancy, for example because it helps in controlling nocturnal blood pressure. ${ }^{26}$ One recent study showed that in women in the third pregnancy trimester who had pre-eclampsia associated with SDB, administration of CPAP resulted in an 
increase in the number of fetal movements and hiccups which were both reduced prior to treatment when compared to a control group. ${ }^{42}$ For women who do not experience snoring but have other symptoms of sleep apnea, for example women with upper airway resistance syndrome (UARS), and then external nasal dilation may be a good solution for reducing the impact of apnea. ${ }^{43}$

\section{POST-PARTUM SLEEP DISORDERS}

Sleep abnormality does not end with delivery, but increases, and the highest drop in total sleep-time occurs during the first month after childbirth. However, many of the sleep disorders associated with the pregnancy itself largely resolve postpartum. For example, incidence of RLS and nocturnal awakening drops substantially in the few months after delivery. ${ }^{6,16,44} \mathrm{~A}$ recent study suggests that, for example, in women with gestational diabetes who experienced SDB during pregnancy, the SDB improved postpartum state to the same levels as healthy subjects. ${ }^{45}$ Postpartum sleep disorders may be largely due to the practicalities of caring for a new baby and other factors, such as heavy menstruation that lasts for up to forty days and physical weakness. However, this does not mean that disordered postpartum sleep should be ignored. One recent study suggests that over half of new mothers continue to suffer from excessive daytime sleepiness eighteen weeks after delivery, with implications for daytime functioning and timing of the return to the workforce. ${ }^{46}$ Also, there is evidence to suggest that both pregnancy-associated and postpartum disordered sleep patterns can impact on postnatal depression. A study using wrist actigraphy to monitor poor sleep maintenance and looking at subjective assessments of sleep in twenty-five healthy primiparous women found that poor sleep maintenance was significantly associated with depression. ${ }^{47}$ Meanwhile, another study on fifty-four pregnant women with insomnia in the third trimester has shown that treating the insomnia with either trazodone or diphenhy- dramine resulted in reduced incidence of postpartum depression compared to women treated with placebo. ${ }^{48}$

\section{CONCLUSIONS AND RECOMMENDATIONS}

Sleep disorders including insomnia, restless legs syndrome, excessive daytime sleepiness and sleepdisordered breathing are commonly experiences in pregnancy, with varying incidence and etiology in the three trimesters. It is increasingly recognised that these sleep disorders in pregnancy are associated with adverse maternal outcomes such as hypertension, pre-eclampsia and gestational diabetes. They have also been linked to adverse fetal outcomes including increased likelihood of cesarean delivery and small-for-gestational age. Mental health disturbances such as increased depressive symptoms both during pregnancy and postpartum have been linked to sleep disorders. It is to be recommended that women at higher risk of sleep disorders should be identified early in pregnancy, for example women with a history of sleep disorders, chronic mood disorders, hypertension, irregular blood pressure upheavals, depression and/or anxiety and women who are obese. Prevention and treatment options can then be planned and executed in a timely manner, be it alterations in sleep hygiene or exercise regime, positional therapy, behavioural therapy or short-term pharmacological intervention where necessary. Continuous positive airway pressure should be considered in cases of sleep-disordered breathing in order to positively influence both maternal and fetal outcomes. Increased awareness of serum levels of ferritin and folate during the earliest period of pregnancy and making sufficient efforts to keep these levels within normal range is also to be recommended for prevention of RLS. Appropriate preventive or treatment options in pregnancy-associated sleep disorders can have a positive impact both within pregnancy and postpartum, for example in reducing incidence of post-natal depressive symptoms and improving both maternal and fetal outcomes. 


\section{REFERENCES}

1. Tauman R. Maternal sleep and fetal outcome. The Open Sleep Journal 2013;6(Suppl 1: M8): 63-7.

2. Lee KA, Zaffke ME, McEnany G. Parity and sleep patterns during and after pregnancy. Obstet Gynecol 2000;95(1):14-8.

3. Pien GW, Schwab RJ. Sleep disorders during pregnancy. Sleep 2004;27(7):1405-17.

4. Oyiengo D, Louis M, Hott B, Bourjeily G. Sleep disorders in pregnancy. Clin Chest Med 2014;35(3):571-87.

5. Morong S, Hermsen B, de Vries N. Sleep-disordered breathing in pregnancy: a review of the physiology and potential role for positional therapy. Sleep Breath 2014;18(1):31-7.

6. Hedman C, Pohjasvaara T, Tolonen U, Suhonen-Malm AS, Myllylä VV. Effects of pregnancy on mothers' sleep. Sleep Med 2002; 3(1):37-42.

7. Dørheim SK, Garthus-Niegel S, Bjorvatn B, Eberhard-Gran M. Personality and perinatal maternal insomnia: A study across childbirth. Behav Sleep Med 2014 Aug 30:1-15. doi: 10.1080/15402002.2014.941063

8. Sahota PK, Jain SS, Dhand R. Sleep disorders in pregnancy. Curr Opin Pulm Med 2003;9(6):477-83.

9. American Academy of Sleep Medicine. Classification outline. International Classification of Sleep Disorders, Revised Diagnostic and Coding Manual. Rochester MN: American Academy of Sleep Medicine; 2000. p.14-7.

10. Hegewald MJ, Crapo RO. Respiratory physiology in pregnancy. Clin Chest Med 2011; 32(1):1-13, vii

11. Moorcroft WH. The need to sleep. Understanding Sleep and Dreaming. $2^{\text {nd }}$ ed. New York: Kluwer Academic/Plenum Publishers; 2005, 2013. p.39-66.

12. Dørheim SK, Bjorvatn B, Eberhard-Gran M. Insomnia and depressive symptoms in late pregnancy: a population-based study. Behav Sleep Med 2012;10(3):152-66.

13. Kızlırmak A, Timur S, Kartal B. Insomnia in pregnancy and factors related to insomnia. Scientific World Journal 2012;2012:197093. doi: 10.1100/2012/197093.

14. Lee KA, Zaffke ME, Baratte-Beebe K. Restless legs syndrome and sleep disturbance during pregnancy: the role of folate and iron. $J$ Womens Health Gend Based Med 2001;10(4): 335-41.

15. Goodman JD, Brodie C, Ayida GA. Restless leg syndrome in pregnancy. BMJ 1988;297 (6656):1101-2.

16. Manconi M, Govoni V, De Vito A, Economou NT, Cesnik E, Casetta I, et al. Restless legs syndrome and pregnancy. Neurology 2004; 63(6):1065-9.

17. Suzuki K, Ohida T, Sone T, Takemura S, Yokoyama E, Miyake T, et al. The prevalence of restless legs syndrome among pregnant women in Japan and the relationship between restless legs syndrome and sleep problems. Sleep 2003;26(6):673-7.

18. Simpson KR, Creehan PA. Pulmonary complications. Perinatal Nursing. $3^{\text {rd }}$ ed. Philadelphia: Wolters Kluwer Health/Lippincott Williams \& Wilkins; 2008. p.226-39.

19. Venkata C, Venkateshiah SB. Sleep-disordered breathing during pregnancy. $\mathrm{J} A \mathrm{~m}$ Board Fam Med 2009;22(2):158-68.

20. Franklin KA, Holmgren PA, Jönsson F, Poromaa N, Stenlund H, Svanborg E. Snoring, pregnancy-induced hypertension, and growth retardation of the fetus. Chest 2000;117(1): 137-41.

21. Sarberg M, Svanborg E, Wiréhn AB, Josefsson $A$. Snoring during pregnancy and its relation to sleepiness and pregnancy outcome - a prospective study. BMC Pregnancy Childbirth 2014 Jan 13;14:15. doi: 10.1186/1471-239314-15.

22. Guilleminault C, Querra-Salva M, Chowdhuri S, Poyares D. Normal pregnancy, daytime sleeping, snoring and blood pressure. Sleep Med 2000;1(4):289-97.

23. Thai $Y$, Henderson M, Carney P, Geyer JD. Women and sleep. In: Carney PR, Berry RB, Geyer JD, eds. Clinical Sleep Disorders. $2^{\text {nd }}$ ed. Philadelphia: Lippincott Williams\&Wilkins; 2012. p. 484-90.

24. Resi NI. Sleep disorders in women. A guide for the nurse practitioner and the physician assistant. In: Attarian HP, Viola-Saltzman M, eds. Sleep Disorders in Women: A Guide to Practical Management. $2^{\text {nd }}$ ed. New York City: Humana Press; 2013. p.25-36.

25. Wang SM, Dezinno P, Maranets I, Berman MR, Caldwell-Andrews AA, Kain ZN. Low back pain during pregnancy: prevalence, risk factors, and outcomes. Obstet Gynecol 2004;104(1):65-70.

26. Mindell JA, Jacobson BJ. Sleep disturbances during pregnancy. J Obstet Gynecol Neonatal Nurs 2000;29(6):590-7.

27. Schweiger MS. Sleep disturbance in pregnancy. A subjective survey. Am J Obstet Gynecol 1972;114(7):879-82.

28. Ursavaş A, Karadağ M. Sleep breathing disorders in pregnancy. Tuberk Toraks 2009; 57(2):237-43.

29. O'Brien L, Bullough A, Chames M, Shelgikar A, Armitage R, Guilleminualt $C$, et al. Hyper- tension, snoring, and obstructive sleep apnoea during pregnancy: a cohort study. BJOG 2014;121(13):1685-93

30. Olivarez SA, Ferres M, Antony K, Mattewal A, Maheshwari B, Sangi-Haghpeykar H, et al. Obstructive sleep apnea screening in pregnancy, perinatal outcomes, and impact of maternal obesity. Am J Perinatol 2011;28(8): 651-8.

31. Srivanitchapoom P, Pandey S, Hallett M. Restless legs syndrome and pregnancy: a review. Parkinsonism Relat Disord 2014;20(7): 716-22.

32. Facco FL, Ouyang DW, Zee PC, Strohl AE, Gonzalez AB, Lim C, et al. Implications of sleep-disordered breathing in pregnancy. Am J Obstet Gynecol 2014;210(6):559.e1-6.

33. O'Brien LM, Bullough AS, Owusu JT, Tremblay KA, Brincat CA, Chames MC, et al. Snoring during pregnancy and delivery outcomes: a cohort study. Sleep 2013;36(11):1625-32.

34. Louis J, Auckley D, Miladinovic B, Shepherd $A$, Mencin P, Kumar D, et al. Perinatal outcomes associated with obstructive sleep apnea in obese pregnant women. Obstet Gynecol 2012;120(5):1085-92.

35. Hung HM, Ko SH, Chen $\mathrm{CH}$. The association between prenatal sleep quality and obstetric outcome. J Nurs Res 2014;22(3):147-54.

36. Lee EK, Gutcher ST, Douglass AB. Is sleepdisordered breathing associated with miscarriages? An emerging hypothesis. Med Hypotheses 2014;82(4):481-5.

37. Mellor R, Chua SC, Boyce P. Antenatal depression: an artefact of sleep disturbance? Arch Womens Ment Health 2014;17(4):291302.

38. Okun ML, Kline CE, Roberts JM, Wettlaufer B, Glover K, Hall M. Prevalence of sleep deficiency in early gestation and its associations with stress and depressive symptoms. J Womens Health (Larchmt) 2013;22(12):1028-37.

39. Ramakrishnan K. Treatment options for insomnia. South African Family Practice 2007;49(8);34-41.

40. Sharma A, Sayeed N, Khees CR, Akhtar S. High dose zolpidem induced fetal neural tube defects. Curr Drug Saf 2011;6(2):128-9.

41. Wang LH, Lin HC, Lin CC, Chen YH, Lin HC. Increased risk of adverse pregnancy outcomes in women receiving zolpidem during pregnancy. Clin Pharmacol Ther 2010;88(3): 369-74.

42. Blyton DM, Skilton MR, Edwards N, Hennessy A, Celermajer DS, Sullivan CE. Treatment of sleep disordered breathing reverses low fetal activity levels in preeclampsia. Sleep 2013; 36(1):15-21. 
43. Bahammam AS, Tate R, Manfreda J, Kryger $\mathrm{MH}$. Upper airway resistance syndrome: effect of nasal dilation, sleep stage, and sleep position. Sleep 1999;22(5):592-8.

44. Hübner A, Krafft A, Gadient S, Werth E, Zimmermann R, Bassetti CL. Characteristics and determinants of restless legs syndrome in pregnancy: a prospective study. Neurology 2013;80(8):738-42.

45. Reid J, Glew RA, Skomro R, Fenton M, Cotton
D, Olatunbosun F, et al. Sleep disordered breathing and gestational hypertension: postpartum follow-up study. Sleep 2013;36(5):717$721 \mathrm{~B}$.

46. Filtness AJ, MacKenzie J, Armstrong K. Longitudinal change in sleep and daytime sleepiness in postpartum women. PLoS One 2014;9(7):e103513.

47. Park EM, Meltzer-Brody S, Stickgold R. Poor sleep maintenance and subjective sleep qual- ity are associated with postpartum maternal depression symptom severity. Arch Womens Ment Health 2013;16(6):539-47.

48. Khazaie H, Ghadami MR, Knight DC, Emamian $F$, Tahmasian M. Insomnia treatment in the third trimester of pregnancy reduces postpartum depression symptoms: a randomized clinical trial. Psychiatry Res 2013;210(3):901-5 